\title{
The characteristics of women soldiers' profession socialization, integration, adaptation and their emphasized fields of manifestation in the different types of corps
}

\author{
GYÖRFFY Ágnes ${ }^{1}$, BOLGÁR Judit ${ }^{2}$
}

\begin{abstract}
The acceptance of women soldiers still poses questions in the organization of Hun- garian Defence Forces although they are more than a countable amount of active members in the last decade. Besides this, their professional socialization in mili-tary jobs could be problematic in some ways. Professional socialization is highly influenced by the type of corps (fighting; fight-supporting; serving-supporting) where the woman soldier fulfils her duty, because henceforth she will adapt herself to the requirements and expectations of the corps in question. In order to map the differences of the corps from this aspect we have organized focus groups and by doing this our "hidden aim" was to promote the acceptance of women soldiers and facilitate them in their socialization. As a result we have gained information on the problematic points of adaptation, also the specification of the different types of corps from this point of view. These data will be shown and interpreted in this article.

Keywords: women soldiers, socialization, characteristics of corps, gender role, stereotypes
\end{abstract}

Women soldiers take a more and more active part in growing proportion in different tasks in different armed and defence forces all around the world, among their male colleagues. [1] The US Army gave its licence to women soldiers to take part in active fighting operations from January of 2013. [2] In the case of Hungarian Defence Forces (HDF) woman soldiers are active participants in all types of corps where the characteristics of the tasks of the corps highly influences the strategy (process) of adaptation that also involves the transformation of their well-built female functioning.

In order to map the process of accommodation, professional socialization and their main focus points, we organized focus groups for woman soldiers from every types of corps of the Hungarian Defence Forces. Besides this we made a mixed group from leaders where all types of corps were included (how the leaders see their woman soldier subordinates) and a group of male soldiers mixed from all types of corps.

1 Head of mental health subdivision at the Central Military Hospital; National University of Public Service, Budapest, Hungary Ph.D. student

2 National University of Public Service, Budapest, Hungary, Professor, Bolgar.Judit@uni-nke.hu 
So the groups were the following: Group of leaders;

1. Group of male soldiers;

2. Women soldier - serving supporting group;

3. Women soldier — fight supporting group;

4. Women soldier - fighting group;

In the focus groups - with two group leaders we discussed the question — in their type of corps what are the main problems, questions that are especially connected to women soldiers or representing the differences in some ways in functioning between male and female soldiers in the military organization. Groups were representative from the aspect of corps types of the HDF and each of them consisted of a maximum of 20 members in order to keep the emotional depth of the topic - altogether 98 persons were included in the groups. The collected data have been overviewed by the group members at the end of the group-work, in order to finalize what to include, what is really representative to the state of women soldiers and what shows only individual cases or tendencies. After doing this a group of psychologists considered the pre-collected data and analysed them both quantitatively and qualitatively. In this analysis process the frequency, the importance to the representative group and the military organi- zation have been taken into consideration too. With the help of the focus groups the process of profession socialization could be traced, especially the phase that follows the centralized military basic training and carried out by the different types of corps, so their system of ex- pectation according to the tasks fulfilled by the corps - for the soldiers and the accommo- dation to it could be followed. In the group of leaders (where the group members were chosen from all types of corps of the HDF, the criteria were to have women soldier subordinates, colleagues in order to have their personal experience) we have the following results: [3]

Strongly emphasized: (presented in many answers)

- The rules of civilian relationships (for example, being polite with a lady) between fe- males and males is often contradictory to the rules of military relationships;

- The lack of standardized expectancies at the level of different corps (different corps different rules and expectancies);

- The different extent of deployability in the case of the two genders;

- Using and abusing gender/sex;

- Different workload based on gender;

- The chances of career and promotions are different for the two sexes.

Emphasized: (It was important in several answers)

- Female colleagues, subordinates as a mode of deriving tension or can easily be blamed;

- The different style of communication of the two sexes can easily lead to conflicts, misunderstanding;

- It is hard to maintain the different roles in the life of a woman especially the soldier family member — woman/wife roles;

- Being female in a masculine organization - you get too many and intensive reactions to your femininity;

- Making generalizations from one single example;

- Different work performance evaluation by the two sexes;

- Prejudication;

- The expectance of functioning in a masculine way. 
Other important content:

- The differences in the extent and method of punishments/evaluation when responsibil- ity is questioned between the two sexes;

- The different relation to systematic work;

- Reinforcement in traditional female gender roles (that can be contradictory to the mil- itary role);

- Putting on the military uniform that is inevitably masculine wear (it is uncomfortable because it does not follow the anatomy of the female body);

- Parallel execution of tasks (females are better in doing that);

- Males usually overestimate the friendly gestures of their female colleagues

- The different relation to authority in the case of the two sexes;

- Being a female leader in a masculine organization is a hard position.

This group can be considered as a kind of pre-phase of the research, where the contents, problems, attitudes connected to woman soldiers could be overviewed. The most empha- sized content that is a surface for presentation of different functioning of the two sexes is the content: "The rules of civilian relationships (for ex. being polite with a lady) between females and males are often contradictory to the rules of military relationships." This could be also a sign that in the process of professional socialization for the military role the general socialization of gender role must be overwritten in some ways. This can lead to behavioural disturbances, because gender role begins to develop right after birth and is also coded before that, while professional socialization to the military role usually starts in the early years of adulthood. [4] So in case of male and female soldiers it is very hard to build a sensitive bal- ance where both socialization processes are presented at the same time. Moreover it could be shifted and influenced when one of the individuals is attracted to the other in the situation or trying to hide or avoid the perceived attraction. This cannot always be made better by strict rules, sometimes it makes it even worse because the situation becomes inflexible. The basis for misunderstanding is usually formed by the non-verbal communication shown in an embrace, that can influence further communication both long-term and short-term. These communication disturbances can lead to other elements of this group of content, where the most powerful disturbance is presented in the content: "Using and abusing gender/sex." This shows some overlapping with the elements of the other emphasized group of content: "Being female in a masculine organization - you get too many and intensive reactions to your fem- ininity" where the reactions show some shift towards gender role socialization. In addition, some overlapping could be observed with the content: "The expectance of functioning in a masculine way" where the reactions shifted towards the military role socialization. The base elements of military professional socialization are mainly closer to the masculine gender role socialization so they could be integrated more easily into personality in case of men than women.

From the strongly emphasized elements the content: "The lack of standardized expec- tancies at the level of different corps (different corps - different rules and expectancies)" also deserves special attention. The different types of corps expecting different behavioural patterns both from their male and female members based on the different tasks and missions they are fulfilling. This can lead to communication disturbances when the different types of corps are working together; in extreme situations it can even lead to revulsion. In cases like this the process of reasoning are mainly connected to gender and not to altering the social- 
ization processes in the corps. Besides this basic military training could be also problematic from this aspect, because the instructors have to take into consideration what type of corps is waiting for the soldier. These differences also can be found in the operational theatre or when changing corps.

Another strongly emphasized element was "The different extent of deployability in the case of the two genders", this content occurs several times different parts and forms of ap- pearance in the other contents. From one side it appears in the content: "It's hard to maintain the different roles in the life of a woman especially the soldier - family member woman/ wife roles". It also effects promotion and the evaluation of performance as the following content shows: "The differences in the extent and method of punishments/evaluation when responsibility is questioned in the two sexes" or "The chances of career and promotions are different in the two sexes" and influences the daily workload: "Different workload based on the gender." In extreme cases both positive and negative discrimination can occur.

Contents of the emphasized group show more personal situations, with more tension. Some contents, as mentioned before, are details or parts of former contents, showing one of their especially emphasized parts. Firstly in this group the content: "Female colleagues, sub- ordinates as a tool of deriving tension or can easily be blamed" is very illustrious. In a strong- ly masculine area a woman-soldier with her pure physical presence could be interpreted as provocation. In most languages the word soldier connects strongly to males, so for female soldiers the word needs some kind of extra expressions. So in a situation full of tension their simple presence can evoke former undefined personal emotions.

Also an important and emphasized content: "The different style of communication of the two sexes can easily lead to conflicts, misunderstanding." The members of the military orga- nization experience the communication disturbances between the two sexes in their everyday life and relationships, but in the organization where the precise and aim orientated communi- cation is essential these disturbances can be presented even harder.

Because male proportion in military organizations are usually higher than females, so the presence of a woman soldier could be a curiosum for her social surroundings. From these sit- uations sometimes the conclusion can be drawn that the woman soldier as an individual could be forced into the background and for the community she will be "the woman soldier" both positively and negatively. This is shown by the content: "Making generalizations from one single example." From this on the attitudes and expectations connected to her will influence the relationships to all the other woman soldiers who enter the military organization after her. Prejudice can also occur before or after her integration in the organization ("prejudice" as content) that the woman soldiers have to cope with as a member of her smaller and bigger community, usually independent of her functioning and attitudes. [5]

Into the "other important contents" group, those contents have been included, that showed a rare presence but have high importance in women soldiers functioning and life. From one of these contents, that cannot be found in the other groups, even overlappingly, is the topic of the uniform: "Putting on the military uniform, which is inevitably masculine wear (it is uncomfortable because it does not follow the anatomy of the female body)" the other import- ant content is the special cases of the female leaders in the masculine organization: "Being a female leader in a masculine organization is a hard position" and last but not at least the differences in the relationship to authority: "The different relation to authority in the case of the two sexes." 
With wearing the uniform, especially true for the field uniform, women soldiers live their military being on the physical level based on experience and this is enforced by the reactions from the outside. The field uniform that is standardized in the HDF definitely follows and fits male anatomy. So wearing this for a female individual leads to ambivalence because it changes the movements, body image and based on these, behaviour. Some woman soldiers talked about their experience that while wearing this uniform they behaved and moved in a more masculine way than in other types of uniform or in a civilian dress.

The position of female leaders in a basically masculine organization is very special. [6] The expectations and their behaviour reactions usually become masculine. Prejudice and negative stereotypes on women can be highly present, that is especially true for female lead- ers with male subordinates. Women's different kind of communication and usually sensitive attitude is more emotional than males and are hardly tolerated and handled by the military or- ganization, in some cases these differences could be overestimated based on their alterations.

The relation to authority is a question of high importance in a highly structured organi- zation, this relation also alters connections to gender and socialization. [7] A manifestation form for this could be when woman-soldiers usually relate in a different way to their leader than their male colleagues. Experience from the early childhood, relation to the father or father figure in the gender role socialization gives a good basis for that and will form the relation to authority for the individual's lifetime. Naturally the basic elements of this process also form in early childhood by males too. This relationship is shaded by the different com- munication and the reaction given to it by the two sexes.

These contents in the case of the other groups or some elements of them will be presented with the following emphasis and quality. According to this in the tables some examples have been included in order to help to understand them more precisely:

Table 1. The result of the male group

\begin{tabular}{|c|l|c|}
\hline Rank & \multicolumn{1}{|c|}{ Contents, aspects } & $\begin{array}{c}\text { Fre- } \\
\text { quency }\end{array}$ \\
\hline \multirow{2}{*}{1.} & $\begin{array}{l}\text { Physical suitability, differences in performance (different expectations) } \\
\text { - lack of suitability }\end{array}$ & 9 \\
\cline { 2 - 3 } & $\begin{array}{l}\text { Using and abusing femininity (promotion facilities in the organization, } \\
\text { positive discrimination against women : training, better network of } \\
\text { relationships) Discrimination in the commander's attitude (performance } \\
\text { evaluation) }\end{array}$ & 9 \\
\hline 2. & Mood changes/swings; High sensitivity (more expressed emotions) & 8 \\
\hline \multirow{2}{*}{3.} & $\begin{array}{l}\text { The use of clothing elements that are not in harmony with the military or- } \\
\text { ganization: clothes, jewellery, feminine wear vs. military uniform (bound } \\
\text { police, pre-paid female underwear for woman-soldiers as discrimination) }\end{array}$ & 7 \\
\cline { 2 - 3 } & $\begin{array}{l}\text { Female/maternal role vs. military role (tasks connected to children, roles } \\
\text { in personal life vs. roles in the organization) - Expectations from the } \\
\text { organization and commitment as an expectation from the side of the } \\
\text { organization }\end{array}$ & 7 \\
\hline
\end{tabular}




\begin{tabular}{|c|l|c|}
\hline \multirow{2}{*}{4.} & $\begin{array}{l}\text { Communication disturbances (paying attention to each other) Curiosity, } \\
\text { inquiry (the Why question) - Altered Focus of problems, alternative } \\
\text { solutions (simplifications or overestimation) }\end{array}$ & 6 \\
\hline \multirow{2}{*}{5.} & Women soldiers' role and place is not clear in the military organization & 4 \\
\cline { 2 - 3 } & $\begin{array}{l}\text { Tension and conflicts between women (the role of balance in the male - } \\
\text { female ratio; the difference in conflict handling) }\end{array}$ & 4 \\
\hline \multirow{2}{*}{6.} & $\begin{array}{l}\text { Having your mate/husband/boyfriend at your workplace (How to handle } \\
\text { the new relationship, advantages and disadvantages of having it inside } \\
\text { the organization) }\end{array}$ & 3 \\
\hline
\end{tabular}

According to the first comprehensive table in the male group the most emphasized con- tents are communication disturbances between the two sexes and expressed emotions. Con- nected to this is that males usually give higher importance to these phenomena and differences than females. So in a group or community that consisted only of men the altering behaviour based on the gender role socialization, and its contradiction to the military role socialization; behaviour based on female gender role socialization (for ex.: decorating your office as if it was your home and castle) are the scenes where the conflicts are mainly manifest.

An interesting item in this group is the mention of positive discrimination in case of women soldiers, although to build discrimination you need both sides to be involved actively.

Also a surprising motive is the resentment of the different standards for physical suitabil- ity - although they are strictly ruled by regulations - because in sports we also have these differences, based on the different anatomical characteristics of the two sexes.

Table 2. Results of women soldiers' group from serving - supporting corps type

\begin{tabular}{|c|l|c|}
\hline Rank & \multicolumn{1}{|c|}{ Content } & $\begin{array}{c}\text { Fre- } \\
\text { quency }\end{array}$ \\
\hline 1. & $\begin{array}{l}\text { Women are hardly accepted as soldiers and their chances of promotion is } \\
\text { also limited - women are forced back to their gender role: Higher } \\
\text { education - lower rank; same rank - different position (hard to accept } \\
\text { a woman as leader in a profession for a man); Lower chances to get } \\
\text { into training for woman-soldiers; Some positions are "protected" from } \\
\text { women (creating situations where the woman soldier simply cannot get } \\
\text { the training needed), Expectations based on the traditional female roles, } \\
\text { for ex.: making coffee; Greeting between man and woman - less respect } \\
\text { for the female in lower rank. }\end{array}$ & 16 \\
\hline 2. & $\begin{array}{l}\text { Female/Maternal role - professional role: Coordinating Tasks connect- } \\
\text { ed to children with professional tasks-restrictions in the maternal role } \\
\text { (the weekend must be enough for your child to recover from illness); } \\
\text { having children vs. preserving your status (the distance from the family } \\
\text { members, lack of grandparental help, taking family into consideration in } \\
\text { organizing duty, extra work) }\end{array}$ & 9 \\
\hline 3. & \begin{tabular}{l} 
Creating types, stereotyping \\
\hline 4.
\end{tabular} & $\begin{array}{l}\text { Boundaries of physical performance } \\
\text { Fomale leader with male subordinates (daily fights), Female leader's } \\
\text { harder position to awake respect than males }\end{array}$ \\
\hline
\end{tabular}


In this type of corps we could see, that the content that appears could be grouped in two main topics, but it is reasonable to show their subcategories or overlapping either because they can represent the shifts of emphasis. The two main categories are: "education — posi- tion — rank" and the differences based on them between males and females and the other is: "roles - role expectations" connected to women soldiers. In the case of the latter, the group members also presented that this could affect not only the acceptance of females as soldiers, but the undifferentiated and hardly catchable picture of the stereotypical woman soldier. This stereotypic picture could be seen by its indistinctiveness on the theoretic level and thoughts. The gaps that could be seen on its indistinctiveness mainly field out with the stereotypical characteristics of the male soldier as an expectation which cannot be fulfilled even with the disclaimer of some parts of the female role.

Table 3. Results of woman soldier's group from fight supporting type of corps

\begin{tabular}{|c|l|c|}
\hline Rank & \multicolumn{1}{|c|}{ Content } & $\begin{array}{c}\text { Fre- } \\
\text { quency }\end{array}$ \\
\hline 1. & $\begin{array}{l}\text { Chances of career - acceptance in the military role } \\
\text { ("she has been promoted only for the reason that she had sex with the } \\
\text { right man") choosing your boyfriend/husband from your own - more } \\
\text { acceptance (protection); professional role vs. military role (contempt } \\
\text { in military topics for woman soldiers - prejudice: "She doesn't know } \\
\text { it...") The task fulfilled by a woman soldier considered of lower value } \\
\text { (differences in evaluation); For the same level of acceptance the woman } \\
\text { soldier has to struggle, Self-confidence in military space: not as an } \\
\text { equivalent partner, shown in hand-shaking }\end{array}$ & 17 \\
\hline 2. & $\begin{array}{l}\text { The coordination of the family (female/maternal) role and the profes- } \\
\text { sional role: Having your career and children; Gender role - military } \\
\text { role; Tasks connected to children, having children - the expectations } \\
\text { from the organization }\end{array}$ & 10 \\
\hline 3. & $\begin{array}{l}\text { Suitability (lower expectations) - differences in physical suitability } \\
\text { 4. }\end{array}$ & $\begin{array}{l}\text { Workload (women can bear a greater workload simultaneously than } \\
\text { men because of their skill at divided attention }\end{array}$ \\
\hline 5. & $\begin{array}{l}\text { The influence of wearing a uniform versus civilian clothing (wearing } \\
\text { field uniform - practical wear) - the masculine cutof the uniform }\end{array}$ & 2 \\
\hline 6. & $\begin{array}{l}\text { Stereotypes - One single example of a certain woman soldier creates a } \\
\text { type (generalization from one negative example) }\end{array}$ & 1 \\
\hline 7. & Camaraderie & 1 \\
\hline
\end{tabular}

From this table we could see that the emphasis shift to another direction in this type of corps. One sign of this are the contents with more tension connected to career and their mix- ture with female gender role and dating. Besides this we can observe that from the groups we could see first here the inevitable importance of the uniform that has its role in civilian life too. It builds in a disturbing way on the personal level that evokes the thought of over - accommodation to the military role that involves the repression of female gender role. [8] Besides these we also could see the phenomena of Camaraderie that has a very special role 
in the male soldiers presented and stereotyped by novels and movies in a very positive way. This can foster adaptation, acceptance both on an individual and group level and could en- force the development of a stabile picture of the woman - soldier in the long-run.

Table 4. Results of woman soldier's group from fighting type of corps

\begin{tabular}{|c|c|c|}
\hline Rank & Content & $\begin{array}{c}\text { Fre- } \\
\text { quency }\end{array}$ \\
\hline 1. & $\begin{array}{l}\text { Chances for a career - acceptance in the military role } \\
\text { Expectancies are different and appreciation is lower; In a masculine po- } \\
\text { sition a male can have a better, faster career; at the same level of knowl- } \\
\text { edge the male soldier is chosen; more struggle for higher positions (lead- } \\
\text { er), no acceptance even for higher performance; From the family side: } \\
\text { the woman has her place at home and not as a soldier: male — female } \\
\text { roles; Respect, tone, behaviour (soft — rough); Struggle for acceptance or } \\
\text { just spending time — not adapting yourself to the organization at all; "the } \\
\text { men must also prove their positions to me!" — Gender roles in the } \\
\text { foreground - You are the "new trend"; generalization — prejudice; In } \\
\text { the evaluation of performance stress-tolerance considered lower than } \\
\text { male, prejudice: "Women shouldn't go on missions!" - You have to pay } \\
\text { more attention to them while you are over there. }\end{array}$ & 22 \\
\hline 2. & $\begin{array}{l}\text { The coordination of the family (female/maternal) role and the profes- } \\
\text { sional role } \\
\text { children - organization of duty + both parents are soldiers?; being away } \\
\text { from your family: taking part in manoeuvres or missions - getting less } \\
\text { information about what it takes to live this way; the conflicts of the fami- } \\
\text { ly (female/maternal) role and the professional role }\end{array}$ & 15 \\
\hline 3. & $\begin{array}{l}\text { Preserving your femininity "signal" — "I'm behaving like a man, but } \\
\text { I'm a woman" } \\
\text { Femininity is lost somewhere: "I'm the terminator both mentally and } \\
\text { physically". First you have to make it clear in yourself how to relate, } \\
\text { what is in the foreground and after doing this you can communicate it to } \\
\text { the outside. Gender-role socialization overwrites the learned rules (for } \\
\text { ex.: problems with hygiene at the operational theatre) }\end{array}$ & 7 \\
\hline 4. & $\begin{array}{l}\text { Suitability: facing the un-acceptance of being female (preparedness; } \\
\text { anatomy; drill, etc.); anatomy - different by the two sexes; women's } \\
\text { physical burden also different (where men walk — women run) — "You } \\
\text { can't do it, lift it, etc." — spoken who can't do it, you can't stay behind } \\
\text { males and can't beat them, because of their vanity. }\end{array}$ & 5 \\
\hline 5. & Uniforms are cut for male anatomy, hygienic circumstances too & 2 \\
\hline 6. & $\begin{array}{l}\text { Mood swings } \\
\text { It can be interpreted as a histrionic reaction when a woman complains } \\
\text { about a serious injury - normal emotional reactions handled as if they } \\
\text { were mood swings. }\end{array}$ & 2 \\
\hline
\end{tabular}


The strongest difference between male and female behaviour is presented in this group. The formerly mentioned contents get other colours, shades, the other side is in the fore-ground, besides these the formerly mentioned contents' other sides highlighted that can form another category. From the examples we could see, that the group members mention deeper, personal experiences with more tension connected to body level than in the former (fight- supporting) group. We could see a stronger frustration at the content: "Chances of career - acceptance in the military role" and some kind of challenge with the men in the question of physical suitability, where "you can't stay behind males and can't beat them, because of their vanity", it contains a lot of tension.

The most powerful content that is shown only in this group is: "Preserving your feminin- ity "signal" — "I'm behaving like a man, but I'm a woman." The members of this group fear losing the feminine side partly or completely is manifested, besides this it also shows that they have to face that even they don't want it. Also unique content is the mention that this type of corps is barely prepared for working with woman soldiers (toilets, showers, bounds, etc.) that can lead to problems with personal hygiene and as a results to different illnesses based on female anatomy.

The summarized results of the groups (from Table 1-4.) can be seen in the following table:

Table 5. Summarized results of the groups

\begin{tabular}{|c|c|c|c|c|}
\hline & \multirow[t]{2}{*}{ Male group } & \multicolumn{3}{|c|}{ Female groups } \\
\hline & & $\begin{array}{l}\text { Serving - } \\
\text { supporting }\end{array}$ & $\begin{array}{l}\text { Fighting - } \\
\text { supporting }\end{array}$ & Fighting \\
\hline $\begin{array}{l}\text { Chances of carrier - accep- } \\
\text { tance in the military role }\end{array}$ & 9 & 16 & 17 & 22 \\
\hline $\begin{array}{l}\text { The coordination of the fam- } \\
\text { ily (female/maternal) role } \\
\text { and the professional role }\end{array}$ & 7 & 9 & 10 & 15 \\
\hline $\begin{array}{c}\text { Suitability - differences in } \\
\text { physical suitability }\end{array}$ & 9 & 4 & 8 & 5 \\
\hline $\begin{array}{l}\text { Creating types, stereotyping } \\
\text { from single examples }\end{array}$ & $\begin{array}{l}\text { not presented } \\
\text { as individual } \\
\text { content }\end{array}$ & 5 & 1 & $\begin{array}{l}\text { not presented } \\
\text { as individual } \\
\text { content }\end{array}$ \\
\hline Wear — Uniform & 7 & $\begin{array}{l}\text { not presented } \\
\text { as individual } \\
\text { content }\end{array}$ & 2 & 2 \\
\hline Conflicts between women & 4 & $\begin{array}{l}\text { not presented } \\
\text { as individual } \\
\text { content }\end{array}$ & $\begin{array}{l}\text { not presented } \\
\text { as individual } \\
\text { content }\end{array}$ & $\begin{array}{l}\text { not presented } \\
\text { as individual } \\
\text { content }\end{array}$ \\
\hline $\begin{array}{l}\text { Having your boyfriend/hus- } \\
\text { band from the workplace }\end{array}$ & 3 & $\begin{array}{l}\text { not presented } \\
\text { as individual } \\
\text { content }\end{array}$ & $\begin{array}{l}\text { not presented } \\
\text { as individual } \\
\text { content }\end{array}$ & $\begin{array}{l}\text { not presented } \\
\text { as individual } \\
\text { content }\end{array}$ \\
\hline $\begin{array}{l}\text { Mood changes/swings - } \\
\text { communication disturbances }\end{array}$ & 8 & $\begin{array}{l}\text { not presented } \\
\text { as individual } \\
\text { content }\end{array}$ & $\begin{array}{l}\text { not presented } \\
\text { as individual } \\
\text { content }\end{array}$ & 2 \\
\hline
\end{tabular}


As we could see from the summarized table that in the women soldier's group from fight- ing type of corps the members show more similarity to the male group than their colleagues from other groups. The contents will be the most emotional in their group. Their accommo- dation pattern is closer to the masculine expectations of the military organization, from this aspect they are followed by the fight-supporting group of woman soldiers and the servingsupporting group is at the other end of the scale. In the case of the last group their profession also requires a civilian education in the military role and forms some kind of balance in their life. The most emphasized content where the tension and alterations connected to women soldiers can appear is shown in the content: "Chances of career acceptance in the military role". This content having its importance by every group that shows that the place and role of women soldiers are still not clear enough in the military organization. On a personal level the content "The coordination of the family (female/maternal) role and the professional role" have priority. The family and social surroundings of the women soldier can also have the experience of how different is the military and civilian world and how the adaptation process changes the behavioural repertoire.

Summarizing the results, the presence of woman-soldiers in the HDF in a greater amount poses a lot of questions, because based on their gender-role socialization and physiology they have different attitudes, building an altered behavioural repertoire than males that can result in a challenge for women soldiers and male soldiers either in the field of acceptance and adaptation concluding from the traditionally masculine functioning of the military orga- nization. Moreover we could observe alterations in this question at the level of the different types of corps, where the shifts of emphasis could be seen on those fields where the adapta- tion process of women soldiers becomes harder. So we could draw the conclusion that it is extremely important to take these aspects also into consideration when facilitating and build- ing the military professional socialization in order to facilitate women soldiers socialization and acceptance.

\section{References:}

[1] BOLGÁR J., KECSKEMÉTHY K.: Nőket a hadseregbe?! Hadtudomány, IX 3 (2001), $25-33$.

[2] MTI: A frontvonalon is beveti a nőket az Egyesült Államok. Origo. 2401 2013. www.origo.hu/nagyvilag/20130124-afrontvonalon-is-beveti-a-noket-az-egyesult-allamok.html (downloaded: 2508 2013)

[3] SZABÓ I. (1994): Bevezetés a szociálpszichológiába. Budapest: Nemzeti Tankönyvkiadó

[4] BALÁZS B.: Nemi sztereotípiák — a szubtípusok szociális értékelése. Alkalmazott pszichológia, 2 (2000), 2742.

[5] TÚRI V.: Az elöítéletek és sztereotípiák megjelenése a katonanők életében. Hadtudományi Szemle, 23 (2009), 101-111.

[6] EAGLY, A. H., CARLI, L. L.: Nők a vezetés útvesztőjében. Harvard Business Review, 9-10. (2007), (12-1) 16-27.

[7] HORKHEIMER, M., FROMM, E., MARCUSE, H.: Studien über Autorität und Familie. Forschungsberichte aus dem Institut für Sozialforschung, 2. Auflage (1987), 77-135.

[8] BUDA B. (1985): Női szerep — női szocializáció — női identitás. In. Koncz K. (szerk.) Nők és férfiak. Hiedelmek és tények. Budapest: MNOT-Kossuth 